Article

\title{
The Impact of Private Research and Development Expenditures and Tax Incentives on Sustainable Corporate Growth in Selected OECD Countries
}

\author{
Dejan Ravšelj and Aleksander Aristovnik * (D) \\ Faculty of Administration, University of Ljubljana, 1000 Ljubljana, Slovenia; dejan.ravselj@fu.uni-lj.si \\ * Correspondence: aleksander.aristovnik@fu.uni-lj.si
}

Received: 10 June 2018; Accepted: 26 June 2018; Published: 4 July 2018

check for updates

\begin{abstract}
Investment in research and development (R\&D) plays a vital role in sustainable economic growth in many countries around the world. In addition, also companies are aware of that R\&D investment is becoming more and more important since it can generate future benefits, which may ultimately result in the sustainable corporate growth. The aim of this paper is to evaluate the impact of private R\&D expenditures and R\&D tax incentives on sustainable corporate growth. Using multiple regression analysis, a panel dataset of 1372 companies investing the largest amounts in $R \& D$ activity is analysed. The results of this paper reveal that private $R \& D$ expenditures as well as $R \& D$ tax incentives (in interaction with private $R \& D$ expenditures) have a positive impact on sustainable corporate growth at the firm level in selected Organisation for Economic Co-operation and Development (OECD) countries. The comparison between different subgroups of companies reveals that private $R \& D$ expenditures represent one of the main driver of sustainable corporate growth especially in high-tech companies, while R\&D tax incentives (in interaction with private R\&D expenditures) are key determinant of sustainable corporate growth in both subgroups of companies. The results may help governments in the formulation of relevant R\&D tax incentive policy in the future.
\end{abstract}

Keywords: private R\&D expenditures; $R \& D$ tax incentives; sustainable corporate growth; multiple regression analysis

\section{Introduction}

The majority of countries around the world are aware that investment in research and development (R\&D) plays a vital role in sustainable economic growth [1-5]. In order to make significant progress in this area, in the so-called Lisbon Strategy the European Union (EU) set an objective to raise R\&D spending to $3 \%$ of GDP by 2010 , where the proportion financed by the business sector should be $2 / 3$ of that total [6]. However, this objective was not achieved. Therefore, this objective was resumed in the European strategy for smart, sustainable and inclusive growth called Europe 2020, which set it as the main objective [7]. The aforementioned suggests that EU sees the potential in private R\&D expenditures. This holds also for Organisation for Economic Co-operation and Development (OECD) countries, since the largest share of R\&D expenditures is made by business sector and it accounts more than $60 \%$ of expenditure on R\&D in the OECD area [8].

Due to the importance of private R\&D investment, governments use different tools of public support in order to encourage companies to invest their additional private funds in R\&D activities. Although the government sector plays a relatively minor role as a performer of $R \& D$ it is a major funder of R\&D performed in the business sector [8]. For this purpose, governments commonly use direct funding through $R \& D$ subsidies and indirect funding through $R \& D$ tax incentives. Companies 
from different countries recognize that the principal drivers that are motivating them to invest more in R\&D include the availability of more types of benefits, enabling them to use a combination of subsidies, tax incentives and so forth [9]. Nevertheless, a comparison between R\&D subsidies and R\&D tax incentives reveals that the latter are currently on the rise, while R\&D subsidies are decreasing [10]. This is mainly because most support schemes expired and new ones have not yet been announced, which is associated with current presence of public financial pressures [11]. This paper focuses only on indirect part of the government funding through R\&D tax incentives and aims at understanding the simultaneous influence of private $R \& D$ investment and $R \& D$ tax incentives on sustainable corporate growth.

In the existing literature, there are many studies addressing the debate whether R\&D investment can improve competitive position of companies and enhance their sustainable growth. However, studies addressing the efficiency of R\&D tax incentives on a corporate level are relatively scarce, mainly due to data limitations. Therefore, this paper tries to add new evidence and consequently to expand previous research by utilising a unique database, which includes all relevant data regarding main resources of production, $R \& D$ tax incentives and corporate performance as well. In terms of the expected results, the research will contribute to both academic and practical knowledge and it is likely to be useful for different stakeholders ranging from policymakers to managers or investors. Currently, the whole world economy strives to become knowledge-based calling for intensive R\&D investment. Since some issues regarding R\&D investment remain unsettled, this paper may help to illuminate certain ambiguities relating to this investment, which is expected to be one of the crucial investments in the future.

This paper tries to consider two issues. First, it tries to evaluate the impact of private R\&D expenditures on sustainable corporate growth. The second part extends the first part by considering private $R \& D$ expenditures and R\&D tax incentives simultaneously. Moreover, both of these parts try to determine whether there are any differences between high-tech and low-tech companies regarding private R\&D expenditures, R\&D tax incentives and sustainable corporate growth. The remaining sections of this paper are organized as follows. In the next section, a literature review and hypotheses development is presented. The following section describes research design covering data description, variables as well as research methodology and model selection. In the fourth section, empirical results are described. The paper ends with discussion and conclusions in which the main findings, policy implications and future research avenues are considered.

\section{Literature Review and Hypotheses Development}

The global economy is currently facing new challenges related to the emergence of new technologies. Hence, ever-greater emphasis is being placed on R\&D at the country and firm level. Traditionally, companies have been focusing their business operations mainly on physical assets. However, this has dramatically changed over the past years. Namely, in the period of industrialization, tangible assets represented the main source of value creation but in the knowledge economy era, $R \& D$ investment has higher potential for value creation compared to tangible assets [12]. Since R\&D investment represents essential determinant for the economic growth, from a society's point of view potential underinvestment is considered as explanation for government intervention to stimulate these kind of investment [13]. Therefore, many governments create and implement different kind of public policies that promote $R \& D$ investment in the business sector and consequently encourage companies to develop new knowledge, skills and innovation in order to facilitate stronger competitiveness, job creation and spur economic development.

Governments use different tools of public support to encourage companies to invest their additional private funds in $R \& D$ activities. In addition to providing direct R\&D support through subsidies, many governments also incentivise company's R\&D indirectly, through tax incentives. While R\&D subsidies have been available to companies for a longer period, R\&D tax incentives have gradually become an important form of public support for boosting companies' R\&D expenditures 
in many countries [14]. In this respect, Figure 1 presents the use of direct and indirect government support for R\&D in business sector for selected OECD countries. Namely, data for Israel, Luxembourg, Poland and Sweden is unavailable or insufficient and therefore these countries are not included in the presentation [15].

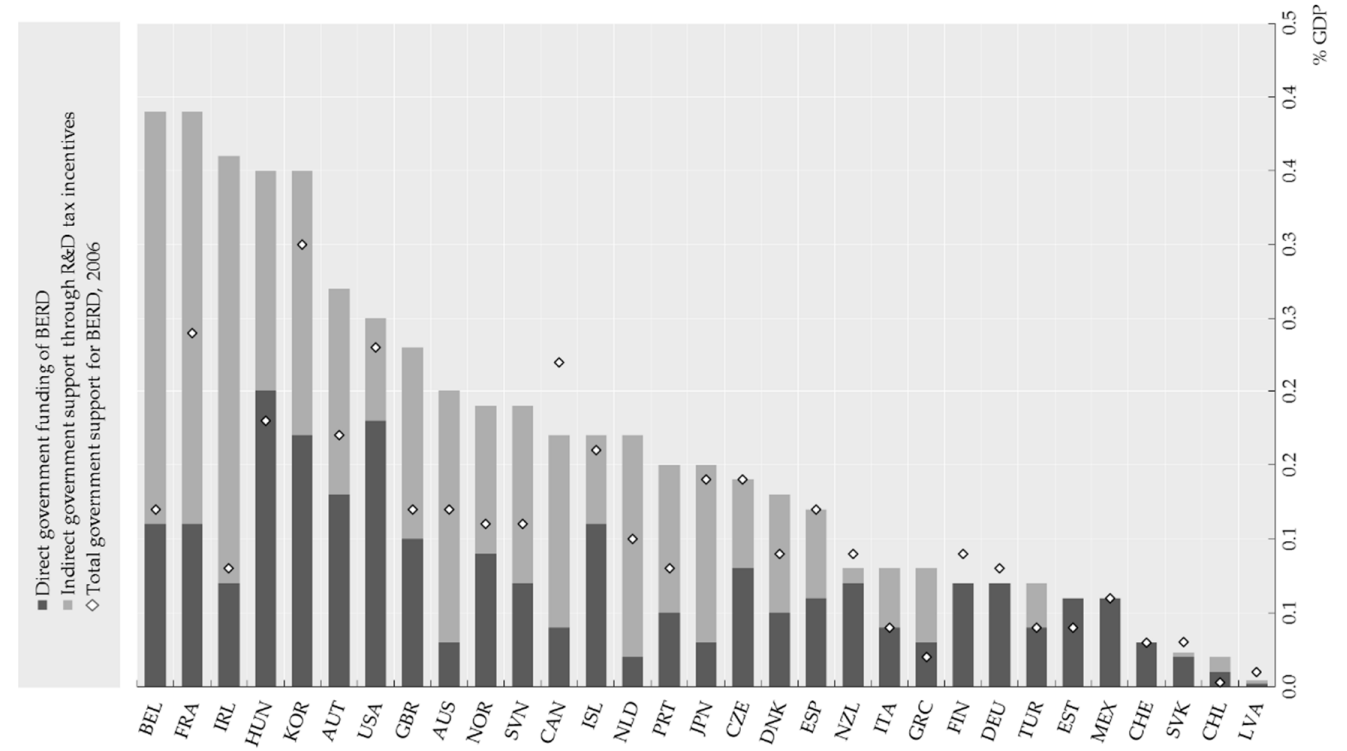

Figure 1. Direct and indirect government support for R\&D in business sector in 2015.

Figure 1 reveals that Belgium and France provided the highest total public support for R\&D in business sector as a percentage of GDP in 2015 among presented OECD countries. A comparison between 2006 and 2015 shows an increase of public support in 21 OECD countries with the highest increase in Ireland and Belgium. Moreover, it is also evident that Hungary and United States have the largest share of GDP for direct support, while Ireland and Belgium have the largest share of GDP for indirect support. In general R\&D tax incentives in 2015 accounted for nearly half of total government support for business R\&D in the OECD area, up from one-third in 2006 [15]. In the literature, there is an ongoing debate on what is more effective for stimulating investments in $R \& D$ : $R \& D$ subsidies or $R \& D$ tax incentives. There is no agreement on this issue since different results suggest different policies and different solutions [16-18]. Regarding the use of direct or indirect public support for R\&D in business sector, there appears to be broad consensus that direct support through R\&D subsidies is more suitable for supporting longer-term, high-risk research and for targeting specific areas that generate public goods or that have particularly high potential for spillovers. In contrast, indirect support through R\&D tax incentives is more suited in principle to encourage $R \& D$ activities oriented towards the development of applications that have the potential to be brought to the market within a reasonable timeframe [19]. Considering the dynamic aspect of the development of both tools of public support for R\&D investment, it is obvious there is a shift towards indirect public support through R\&D tax incentives in OECD countries. This suggests that $R \& D$ tax incentives are gaining more importance and have become a major tool for promoting business R\&D in OECD countries.

In the literature, it is emphasized that sustainable economic growth depends on the application of new knowledge in order to develop improved products and production processes. Several authors argue that $R \& D$ investment is one of the key factors for enhancing technological progress and economic growth at national level [20-22]. In this regard, Silaghi et al. [23] also separate R\&D into private and public $R \& D$, whereby the results of their analysis show a significantly significant impact of private R\&D on economic growth, while public R\&D remains not significant. However, public R\&D does not crowd out the positive effect of private R\&D. Further, Armeanu et al. [24] try to identify the main drivers of sustainable economic growth in EU member countries. They establish that R\&D 
expenditures have a positive impact on economic growth as well as on total factor productivity, which can also enhance growth. While the aforementioned macroeconomic analyses reveal the positive impact of R\&D investment on economic and sustainable growth, microeconomic analyses show that R\&D expenditures have a positive impact on corporate performance, which is proven by studies from different countries around the world [25-31]. Investment in R\&D can be therefore expected to enhance corporate growth [32]. Brief literature review reveals beneficial effect of R\&D expenditures on national and corporate growth. The aforementioned represents one of the main reason why are companies increasingly motivated to invest in R\&D activities. Moreover, the shift from industrial to knowledge-based economy has significantly increased the importance of $R \& D$ investment since in such era; it has higher potential for value creation compared to tangible assets, especially in terms of improving competitive position of companies and enhancing their sustainable growth. Based on the above, the first research hypothesis is proposed:

Hypothesis 1. Private RED expenditures have a positive impact on sustainable corporate growth at the firm level in selected OECD countries.

Although R\&D investment can bring certain benefits for the companies, the companies' motivation for such investment can still be questionable. The reason behind this is that the amount of R\&D investment that is socially optimal is in general larger than privately optimal R\&D investment [33]. Private $R \& D$ expenditures are therefore broadly thought to be underinvested compared to what is socially optimal. This is mainly due to the imperfect appropriability of new knowledge on the one hand and gaps in financing caused by information asymmetry on the other $[34,35]$. Therefore, governments in many countries provide tools of public support to enhance R\&D activity both directly or indirectly. In this respect, Svoboda [36] investigates the impact of R\&D tax incentives by comparing its effectiveness to R\&D subsidies at a macro level in selected OECD countries. The results of his study suggest that $R \& D$ tax incentives are more effective than $R \& D$ subsidies. These results can therefore partially explain why R\&D tax incentives have become a central part of economic policies in many countries all around the world. There exist also some empirical studies at a micro level establishing that $R \& D$ tax incentives have a positive effect on companies $R \& D$ expenditures [37-42]. Compared to studies, which examine the effect of R\&D tax incentives on the companies' R\&D expenditures, there are only few studies, which examine the direct effect of R\&D tax incentives on corporate performance and growth. Czarnitzki et al. [41] investigate the effect of R\&D tax incentives on innovation activities of manufacturing companies in Canada. The results of this study show that R\&D tax incentives recipients realize a higher number of product innovations, as well as increased sales shares of new and improved products. Moreover, there is also some evidence in the literature about a positive relationship between the use of $R \& D$ tax incentives and the probability of introducing a world first innovation [43]. The literature review reveals encouraging results of terms of the positive impact on private $R \& D$ investment, innovation output, corporate performance and corporate growth. Namely, there is scarce evidence confirming that, besides R\&D investment, the generosity of R\&D tax incentives also have a positive effect on sustainable corporate growth [44,45]. Based on the above, the following second research hypothesis is proposed:

Hypothesis 2. RED tax incentives (in interaction with private RED expenditures) have a positive impact on sustainable corporate growth at the firm level in selected OECD countries.

\section{Research Design}

\subsection{Data Description}

The paper focuses on evaluating the effects of private $R \& D$ expenditures and $R \& D$ tax incentives (in interaction with private R\&D expenditures) on sustainable corporate growth. The empirical analysis is performed on top corporate R\&D investors from selected OECD countries and from different 
industries. In order to create a unique dataset, data for the empirical analysis is taken and merged from two different main sources containing all relevant data for the empirical analysis, whereby the data regarding $R \& D$ tax incentives is in terms of recentness and consecutiveness available only for 2015 and 2016.

The first source is EU Industrial R\&D Investment Scoreboard, which contains financial information on the top R\&D corporate investors [46,47]. Data regarding main resources of production and corporate performance is obtained from two different data sets, whereby the first one comprises 2500 companies at the world level and the second one covers 1000 companies at the EU level. Since there is an overlap between the aforementioned sources, both are combined in a single dataset by eliminating overlapping companies. In order to identify those companies, which are more continuously engaged in $R \& D$ investment, only those for which all relevant data is available for latest consecutive years are considered in the empirical analysis. In this way, the data for 1432 companies is obtained. By checking the distribution of the companies by countries, it is identified that some countries have a very low share of companies compared to the whole sample. These companies cannot be representative for a certain country and therefore they are eliminated from the empirical analysis. After adjustments, the final number of companies included in the analysis is 1372 companies. By considering the same conditions regarding companies' substantial R\&D investment for two consecutive years and selected OECD countries, there are 1808 companies covered in the EU Industrial R\&D Investment Scoreboard. The comparison reveals that the companies included in the empirical analysis represent $75.88 \%$ of overall number of companies covered in the EU Industrial R\&D Investment Scoreboard, whereby companies with missing data represent the remaining $24.12 \%$ share. Further, this database was merged with the second source represented by OECD database, which provides a proxy for R\&D tax incentives, namely R\&D tax subsidy ratio (1-B index) [48].

To summarize, the final number of companies included in the empirical analysis is 1372 companies from selected OECD countries and from different industries. Table 1 presents the distribution of the companies by countries, while Table 2 presents the distribution of the companies by industries.

Table 1. Distribution of the companies by countries.

\begin{tabular}{ccccc}
\hline \multirow{2}{*}{ Country } & \multicolumn{2}{c}{$\begin{array}{c}\text { Companies Included in the } \\
\text { Empirical Analysis }\end{array}$} & $\begin{array}{c}\text { Companies Covered by the EU } \\
\text { Industrial R\&D Investment Scoreboard }\end{array}$ \\
\cline { 2 - 5 } & Number & Share (in \%) & Number & Share (in \%) \\
\hline Austria & 18 & 1.31 & 25 & 1.38 \\
Denmark & 18 & 1.31 & 29 & 1.60 \\
Finland & 25 & 1.82 & 32 & 1.77 \\
France & 73 & 5.32 & 95 & 5.25 \\
Germany & 110 & 8.02 & 180 & 9.96 \\
Ireland & 20 & 1.46 & 21 & 1.16 \\
Italy & 27 & 1.97 & 34 & 1.88 \\
Japan & 292 & 21.28 & 332 & 2.36 \\
Sweden & 46 & 3.35 & 41 & 3.76 \\
Switzerland & 41 & 2.99 & 68 & 2.77 \\
Netherlands & 23 & 1.68 & 50 & 11.50 \\
United & 97 & 7.07 & 208 & 38.33 \\
Kingdom & & & 693 & 100 \\
United States & 582 & 42.42 & 1808 & \\
Total & 1372 & 100 & & \\
\hline
\end{tabular}

From the Table 1 it is evident that the share of top corporate R\&D investors included in the analysis varies considerably between the selected OECD countries. The largest shares of top corporate R\&D investors have United States, Japan and Germany. On the other hand, the lowest share Ireland, Austria and Denmark. The distribution of the companies included in the empirical analysis coincides with the distribution of the companies covered by the EU Industrial Investment Scoreboard. Therefore, it can 
be concluded that sample, which is used in the empirical analysis is meaningful in terms of evaluating the impact of private $R \& D$ expenditures and $R \& D$ tax incentives on sustainable corporate growth by considering top corporate R\&D investors in selected OECD countries. Moreover, distribution of the companies, which is presented in Table 2, shows that there is also uneven distribution of top corporate $R \& D$ investors between different industries.

Table 2. Distribution of the companies by industries.

\begin{tabular}{|c|c|c|c|c|c|}
\hline & \multirow[t]{2}{*}{ Industry } & \multicolumn{2}{|c|}{$\begin{array}{l}\text { Companies Included in } \\
\text { the Empirical Analysis }\end{array}$} & \multicolumn{2}{|c|}{$\begin{array}{l}\text { Companies Covered by the EU } \\
\text { Industrial R\&D Investment Scoreboard }\end{array}$} \\
\hline & & Number & Share (in \%) & Number & Share (in \%) \\
\hline \multirow{16}{*}{ HT } & Aerospace \& Defence & 31 & 2.26 & 35 & 1.94 \\
\hline & Automobiles \& Parts & 81 & 5.90 & 103 & 5.70 \\
\hline & Chemicals & 91 & 6.63 & 108 & 5.97 \\
\hline & Electronic \& Electrical Equipment & 121 & 8.82 & 149 & 8.24 \\
\hline & General Industrials & 43 & 3.13 & 58 & 3.21 \\
\hline & Health Care Equipment \& Services & 72 & 5.25 & 93 & 5.14 \\
\hline & Household Goods \& Home Construction & 27 & 1.97 & 33 & 1.83 \\
\hline & Industrial Engineering & 135 & 9.84 & 170 & 9.40 \\
\hline & Leisure Goods & 19 & 1.38 & 25 & 1.38 \\
\hline & Mobile Telecommunications & 11 & 0.80 & 12 & 0.66 \\
\hline & Personal Goods & 32 & 2.33 & 34 & 1.88 \\
\hline & Pharmaceuticals \& Biotechnology & 171 & 12.46 & 296 & 16.37 \\
\hline & Software \& Computer Services & 169 & 12.32 & 211 & 11.67 \\
\hline & Support Services & 19 & 1.38 & 39 & 2.16 \\
\hline & Technology Hardware \& Equipment & 130 & 9.48 & 159 & 8.79 \\
\hline & Total high-tech & 1152 & 83.97 & 1525 & 84.35 \\
\hline \multirow{21}{*}{ LT } & Alternative Energy & 5 & 0.36 & 5 & 0.28 \\
\hline & Beverages & 4 & 0.29 & 5 & 0.28 \\
\hline & Construction \& Materials & 38 & 2.77 & 48 & 2.65 \\
\hline & Electricity & 13 & 0.95 & 18 & 1.00 \\
\hline & Financial Services & 14 & 1.02 & 19 & 1.05 \\
\hline & Fixed Line Telecommunications & 7 & 0.51 & 9 & 0.50 \\
\hline & Food \& Drug Retailers & 3 & 0.22 & 3 & 0.17 \\
\hline & Food Producers & 35 & 2.55 & 51 & 2.82 \\
\hline & Forestry \& Paper & 8 & 0.58 & 10 & 0.55 \\
\hline & Gas, Water \& Multiutilities & 12 & 0.87 & 13 & 0.72 \\
\hline & General Retailers & 9 & 0.66 & 14 & 0.77 \\
\hline & Industrial Metals \& Mining & 16 & 1.17 & 19 & 1.05 \\
\hline & Industrial Transportation & 5 & 0.36 & 9 & 0.50 \\
\hline & Media & 14 & 1.02 & 19 & 1.05 \\
\hline & Mining & 4 & 0.29 & 5 & 0.28 \\
\hline & Oil \& Gas Producers & 12 & 0.87 & 12 & 0.66 \\
\hline & Oil Equipment, Services \& Distribution & 5 & 0.36 & 6 & 0.33 \\
\hline & Tobacco & 5 & 0.36 & 5 & 0.28 \\
\hline & Travel \& Leisure & 11 & 0.80 & 13 & 0.72 \\
\hline & Total low-tech & 220 & 16.03 & 283 & 15.65 \\
\hline & Total & 1372 & 100 & 1808 & 100 \\
\hline
\end{tabular}

Table 2 reveals that the largest share of top corporate R\&D investors, which are included in the empirical analysis, belongs to high-tech industries, especially to Pharmaceuticals \& Biotechnology and Software \& Computer Services. Among low-tech industries, Construction \& Materials and Food Producers present the industries with the highest share of top corporate R\&D investors, which are included in the analysis. Moreover, it is evident that the distribution of the companies included in the empirical analysis coincides with the distribution of the companies covered by the EU Industrial Investment Scoreboard. Therefore, it can be concluded that sample, which is used in the empirical analysis is meaningful in terms of evaluating the impact of private R\&D expenditures and R\&D tax incentives on sustainable corporate growth by considering the industry of top corporate R\&D investors in selected OECD countries. 


\subsection{Variables}

The aim of this paper is twofold. First, it tries to evaluate the impact of private R\&D expenditures on sustainable corporate growth. The second part of the paper tries to extend the previous one by evaluation the impact of R\&D tax incentives on sustainable corporate growth by taking into account the interaction with private R\&D expenditures. In both parts, also other relevant factors of influence, such as capital and labour, are considered.

Sustainable corporate growth can be defined in numerous ways. It can be defined in terms of revenue generation, value addition and expansion in terms of volume of the business. Moreover, it can also be measured in the form of qualitative features like market position, quality of product and goodwill of the customers [49]. In this paper, sustainable corporate growth is measured as one-year net sales growth expressed as a percentage. Namely, net sales growth represents one of the fundamental determinant driving sustainable corporate growth.

In this paper, two main independent variables of interest are used, namely private R\&D expenditures and $R \& D$ tax incentives. Private $R \& D$ expenditures is the cash investment funded by the companies themselves. It excludes R\&D undertaken under contract for customers such as governments or other companies. It also excludes the companies' share of any associated company or joint venture $R \& D$ investment $[46,47]$. $R \& D$ tax incentives are calculated as a product of a proxy for $R \& D$ tax credits (1-B index) of a certain country, which is often reported as $R \& D$ tax subsidy ratio and private $R \& D$ expenditures. $R \& D$ tax subsidy ratio represents the proportion of one euro of $R \& D$ expenditure that is subsidized by $R \& D$ tax incentives. This means that the higher the $R \& D$ tax subsidy ratio, the more generous the R\&D tax incentives [50]. In the calculation of R\&D tax incentives for each company, it is assumed that all of the companies included in the analysis are taxable and may enjoy the full benefit of the R\&D tax incentives. The interaction between the proxy for $R \& D$ tax incentives and private $R \& D$ expenditures therefore represent an approximation of benefits that the company has from $R \& D$ tax incentives by taking into account the simultaneous impact of private $R \& D$ expenditures. Both of main independent variables of interest are measured as one-year growth expressed as a percentage.

Since sustainable corporate growth is affected by many other factors, approximations for capital (capital expenditures) and labour (number of employees) are also considered in the paper. Capital expenditures are expenditures used by a company to acquire or upgrade physical assets such as equipment, property and industrial buildings. Number of employees represent the total consolidated average employees or year-end employees if average not stated. Both of these variables are measured as one-year growth expressed as a percentage [46,47]. Finally, a time dummy variable is also considered in order to control for year effect. A summary of all variables used in the empirical analysis is presented in Table 3.

Table 3. Abbreviations and definitions of variables.

\begin{tabular}{|c|c|c|c|}
\hline Abbreviation & Variable & Definition & Unit of Measurement \\
\hline NSG & Net sales growth & $\begin{array}{l}\text { Net sales growth is simple growth of } \\
\text { net sales over the previous year. }\end{array}$ & Percentage \\
\hline RDG & R\&D growth & $\begin{array}{l}\text { R\&D growth is simple growth of } R \& D \\
\text { expenditures over the previous year. }\end{array}$ & Percentage \\
\hline RDTIG & $\begin{array}{l}\text { R\&D tax incentives } \\
\text { growth }\end{array}$ & $\begin{array}{l}\text { R\&D tax incentives growth is simple } \\
\text { growth of } R \& D \text { tax incentives over the } \\
\text { previous year. }\end{array}$ & Percentage \\
\hline CAPEXG & $\begin{array}{l}\text { Capital expenditure } \\
\text { growth }\end{array}$ & $\begin{array}{l}\text { Capital expenditure growth is simple } \\
\text { growth of capital expenditure over the } \\
\text { previous year. }\end{array}$ & Percentage \\
\hline EMPG & Employment growth & $\begin{array}{l}\text { Employment growth is simple growth } \\
\text { of number of employees over the } \\
\text { previous year. }\end{array}$ & Percentage \\
\hline YR2016 & Time variable & $\begin{array}{l}\text { Time variable is defined as a dummy } \\
\text { variable, whereby for } 2016 \text { value is } 1 \\
\text { and } 0 \text { otherwise. }\end{array}$ & Binary \\
\hline
\end{tabular}


Since companies represent a very heterogeneous group of units, there may be some outliers in the data. Descriptive statistics of variables included in the empirical analysis (except time dummy variable) suggests that there may be presence of certain outliers in the data. In order to eliminate the effect of possibly spurious outliers, all of the presented variables (except time dummy variable) are winsorized at 5\% and 95\% level by each year. Descriptive statistics for both original (Panel A) and winsorized (Panel B) variables is presented in Table 4.

Table 4. Descriptive statistics of variables.

\begin{tabular}{|c|c|c|c|c|}
\hline Variable & Mean & Std. Dev. & Min & Max \\
\hline \multicolumn{5}{|c|}{ Panel A: Descriptive Statistics of Original Variables } \\
\hline NSG & 27.67 & 575.24 & -97.92 & $28,311.61$ \\
\hline RDG & 11.19 & 43.58 & -82.32 & 1183.33 \\
\hline RDTIG & 0.83 & 6.80 & -17.46 & 307.67 \\
\hline CAPEXG & 27.06 & 208.11 & -99.38 & 5289.38 \\
\hline EMPG & 6.60 & 25.81 & -82.93 & 780.71 \\
\hline \multicolumn{5}{|c|}{ Panel A: Descriptive Statistics of Winsorized Variables } \\
\hline NSG & 6.09 & 15.21 & -19.10 & 48.92 \\
\hline RDG & 8.78 & 18.72 & -20.58 & 65.00 \\
\hline RDTIG & 0.52 & 1.37 & -1.79 & 4.75 \\
\hline CAPEXG & 10.64 & 40.37 & -52.29 & 120.18 \\
\hline EMPG & 5.48 & 12.48 & -13.96 & 44.14 \\
\hline
\end{tabular}

Table 5 shows Pearson correlation between estimated variables (except time dummy variable). The simple correlation indicates a strong correlation between R\&D growth and R\&D tax incentives growth. However, these variables are not included in the same empirical model. R\&D growth represent the main independent variable of interest in the first model, while R\&D tax incentives growth represent the main variable of interest in the second model. The simple correlation between other variables does not indicate any strong linear relationship, suggesting that there is no issue of multicollinearity in the data.

Table 5. Pearson correlation matrix of variables.

\begin{tabular}{|c|c|c|c|c|c|}
\hline Variables & NSG & RDG & RDTIG & CAPEXG & EMPG \\
\hline NSG & 1 & & & & \\
\hline RDG & $0.4574^{* * *}$ & 1 & & & \\
\hline RDTIG & $0.3258^{* * *}$ & $0.7813^{* * *}$ & 1 & & \\
\hline CAPEXG & $0.2988^{* * *}$ & $0.2857^{* * *}$ & $0.2294^{* * *}$ & 1 & \\
\hline EMPG & $0.5348^{* * *}$ & $0.5089^{* * *}$ & $0.3544^{* * *}$ & $0.3332^{* * *}$ & 1 \\
\hline
\end{tabular}

\subsection{Research Methodology and Model Selection}

The first part of the empirical analysis tries to evaluate the impact of private R\&D expenditures (R\&D growth) on sustainable corporate growth (net sales growth). Therefore, dependent variable (net sales growth) is regressed against the first main independent variable of interest (R\&D growth) alongside other relevant factors of influence, namely capital (capital expenditure growth) and labour (employment growth). In order to control for year effect, also a time dummy variable is taken into consideration. Regarding the explained, the following regression model Equation (1) is estimated:

$$
\mathrm{NSG}_{i, t}=\alpha_{i}+\beta_{1} \mathrm{RDG}_{i, \mathrm{t}}+\beta_{2} \mathrm{CAPEXG}_{i, \mathrm{t}}+\beta_{3} \mathrm{EMPG}_{i, t}+\beta_{4} \mathrm{YR}_{2016_{i, t}}+\varepsilon_{i, t}
$$

The second part of the empirical analysis, which is covered in this paper, tries to complement the first part by evaluating the impact of $R \& D$ tax incentives ( $R \& D$ tax incentives growth) on 
sustainable corporate growth (net sales growth) by taking into account the interaction with private $R \& D$ expenditures. Therefore, dependent variable (net sales growth) is regressed against the second main independent variable of interest ( $R \& D$ tax incentives growth) alongside other relevant factors of influence, namely capital (capital expenditure growth) and labour (employment growth). In order to control for year effect, also a time dummy variable is taken into consideration. Regarding the explained, the following regression model Equation (2) is estimated:

$$
\mathrm{NSG}_{i, \mathrm{t}}=\alpha_{\mathrm{i}}+\beta_{1} \mathrm{RDTIG}_{\mathrm{i}, \mathrm{t}}+\beta_{2} \mathrm{CAPEXG}_{\mathrm{i}, \mathrm{t}}+\beta_{3} \mathrm{EMPG}_{\mathrm{i}, \mathrm{t}}+\beta_{4} \mathrm{YR}_{2016_{i, t}}+\varepsilon_{\mathrm{i}, \mathrm{t}}
$$

In order to determine which empirical model (fixed effects, random effects or pooled regression) is the most suitable for the analysis of the relationship between private $R \& D$ expenditures, $R \& D$ tax incentives and corporate growth, three-step procedure is applied. First, LM test is used in order to decide between random effects and pooled regression model. Second, F test is applied in order to compare between pooled regression and fixed effects model. Third, the Hausman test is conducted in order to choose between a random effects and a fixed effects model. The results of aforementioned tests for each model and subsample are presented in Table 6.

Table 6. Tests for model selection.

\begin{tabular}{ccccccc}
\hline \multirow{2}{*}{ Test } & \multicolumn{2}{c}{$\begin{array}{c}\text { Relationship between R\&D Expenditures } \\
\text { and Sustainable Corporate Growth }\end{array}$} & \multicolumn{2}{c}{$\begin{array}{c}\text { Relationship between R\&D Tax Incentives } \\
\text { and Sustainable Corporate Growth }\end{array}$} \\
\cline { 2 - 6 } & $\begin{array}{c}\text { All } \\
\text { Companies }\end{array}$ & $\begin{array}{c}\text { High-Tech } \\
\text { Companies }\end{array}$ & $\begin{array}{c}\text { Low-Tech } \\
\text { Companies }\end{array}$ & $\begin{array}{c}\text { All } \\
\text { Companies }\end{array}$ & $\begin{array}{c}\text { High-Tech } \\
\text { Companies }\end{array}$ & $\begin{array}{c}\text { Low-Tech } \\
\text { Companies }\end{array}$ \\
\hline LM test & $4.79^{*}$ & 2.14 & $12.92^{* * *}$ & $8.68^{* *}$ & $4.13^{*}$ & $17.31^{* * *}$ \\
F test & $169.43^{* * *}$ & $129.07^{* * *}$ & $43.48^{* * *}$ & $195.86^{* * *}$ & $154.61^{* * *}$ & $39.91^{* * *}$ \\
Hausman & $174.24^{* * *}$ & $131.71^{* * *}$ & $48.53^{* * *}$ & $201.26^{* * *}$ & $157.78^{* * *}$ & $44.38^{* * *}$ \\
\hline
\end{tabular}

According to Table 6, the results of LM test is significant for all models and subsamples (except for high-tech companies) suggesting that random effects model is more appropriate. Further, the results of $\mathrm{F}$ test and Hausman test for all models and subsamples reveal that fixed effects model is more suitable than random effects or pooled regression model. Moreover, in the empirical analysis, it is necessary to take into account that companies differ from one another due to different market conditions. The results of these tests seem to be reasonable, since fixed effect model assumes that something within the company may affect or bias the predictor or outcome variables and therefore it is necessary to control for this [51]. Therefore, the fixed effects model represents the baseline model in this paper. However, random effects and pooled regression model are also applied in order to check whether the results are robust to alternative econometric specifications.

\section{Empirical Results}

In the first part of the analysis, multiple regression analysis in different econometric specifications (fixed effects, random effects and pooled regression model) is applied to evaluate the impact of private R\&D expenditures on sustainable corporate growth. First, the empirical model is tested for all companies. Further, the empirical model is tested for different subgroups of companies separately in order to determine whether there are differences between high-tech and low-tech companies. The empirical results are presented in Table 7. 
Table 7. Fixed effects, random effects and pooled regression results for the relationship between R\&D expenditures and sustainable corporate growth.

\begin{tabular}{|c|c|c|c|c|c|c|c|c|c|}
\hline \multirow{3}{*}{$\begin{array}{c}\text { Sample and } \\
\text { Dependent Variable }\end{array}$} & \multicolumn{3}{|c|}{ All Companies } & \multicolumn{3}{|c|}{ High-Tech Companies } & \multicolumn{3}{|c|}{ Low-Tech Companies } \\
\hline & \multicolumn{3}{|c|}{ NSG } & \multicolumn{3}{|c|}{ NSG } & \multicolumn{3}{|c|}{ NSG } \\
\hline & FE & RE & Pooled & FE & RE & Pooled & FE & RE & Pooled \\
\hline RDG & $0.1341^{* * *}$ & $0.1880^{* * *}$ & $0.1892^{* * *}$ & $0.1521^{* * *}$ & $0.2034^{* * *}$ & $0.2039^{* * *}$ & 0.0425 & $0.1119 * * *$ & $0.1303^{* * *}$ \\
\hline CAPEXG & $0.0243 * *$ & $0.0382 * * *$ & $0.0394^{* * *}$ & 0.0208 * & $0.0358^{* * *}$ & $0.0369^{* * *}$ & 0.0288 & $0.0556 * *$ & $0.0613 * *$ \\
\hline EMPG & $0.1749 * * *$ & $0.4467 * *$ & $0.4642 * * *$ & $0.1947^{* * *}$ & $0.4703^{* * *}$ & $0.4836^{* * *}$ & $0.1676^{*}$ & $0.4406 * * *$ & $0.5216^{* * *}$ \\
\hline YR2016 & $-0.9212 *$ & -0.4045 & -0.3747 & -0.6966 & -0.1048 & -0.0786 & -1.3116 & -1.2527 & -1.2385 \\
\hline Constant & $4.1581^{* * *}$ & $1.7897 * * *$ & $1.6553 * * *$ & $4.6822 * * *$ & 2.0226 & $1.9097^{* * *}$ & $1.6142 * *$ & 0.6766 & 0.4176 \\
\hline$R^{2}$ & 0.3308 & 0.3421 & 0.3421 & 0.3283 & 0.3377 & 0.3366 & 0.3269 & 0.3386 & 0.3387 \\
\hline Obs. & \multicolumn{3}{|c|}{2744} & \multicolumn{3}{|c|}{2304} & \multicolumn{3}{|c|}{440} \\
\hline
\end{tabular}


The results of fixed effects model presented in Table 7 reveal that besides the growth in classical production factors (capital and labour) also R\&D growth has a positive and significant impact on sustainable corporate growth in the case of all companies included in the analysis. The aforementioned holds also for high-tech companies. However, the results for low-tech companies indicate that only employment growth has a positive impact on sustainable corporate growth. Considering other econometric specifications (random effects and pooled regression model), the results for all production factors are significant also for low-tech companies. Based on the results of fixed effects model representing the baseline model in this paper from which the main conclusions are derived, Hypothesis 1 , that private $R \& D$ expenditures have a positive impact on sustainable corporate growth at the firm level in selected OECD countries is supported. However, this applies mainly to high-tech companies since R\&D growth is not significant when considering only low-tech companies in the analysis.

The second part of the analysis, multiple regression analysis in different econometric specifications (fixed effects, random effects and pooled regression model) is applied to evaluate the impact of $R \& D$ tax incentives on sustainable corporate growth by taking into account the interaction with private $R \& D$ expenditures. First, the model is tested for all companies. Further, the model is tested for different subgroups of companies separately in order to determine whether there are differences between high-tech and low-tech companies. The empirical results are presented in Table 8.

The results of fixed effects model presented in Table 8 show that besides the growth in classical production factors (capital and labour) also R\&D tax incentives growth has a positive and significant impact on sustainable corporate growth in the case of all companies included in the analysis. The aforementioned holds also for high-tech companies. The results for low-tech companies indicate that only employment growth and R\&D tax incentives growth have a positive and significant impact on sustainable corporate growth. Considering other econometric specifications (random effects and pooled regression model), the results for all production factors are significant also for low-tech companies. Based on the results of fixed effects model representing the baseline model in this paper from which the main conclusions are derived, Hypothesis 2, that $R \& D$ tax incentives (in interaction with private $R \& D$ expenditures) have a positive impact on sustainable corporate growth at the firm level in selected OECD countries is supported. Moreover, the results suggest that R\&D tax incentives (in interaction with private R\&D expenditures) improve sustainable corporate growth also in low-tech companies.

The results of the empirical analysis seem to be reasonable. They suggest that private R\&D expenditures as well as $R \& D$ tax incentives (in interaction with private $R \& D$ expenditures) have a positive impact on sustainable corporate growth at the firm level in selected OECD countries. However, by considering different subgroups of companies, the empirical results become more interesting. In the case of high-tech companies, the results reveal the positive and significant impact of private $R \& D$ expenditures and $R \& D$ tax incentives on sustainable corporate growth. This is not the case in low-tech companies since the results suggest that sustainable corporate growth of these companies is not stimulated by private $R \& D$ expenditures. On the other hand, $R \& D$ tax incentives (in interaction with private R\&D expenditures) represent the determinant of sustainable corporate growth in low-tech companies. Nevertheless, the comparison between different subgroups of companies reveals much higher values of regression coefficients, suggesting that the impact $R \& D$ tax incentives (in interaction with private $R \& D$ expenditures) is more prominent in high-tech companies. 
Table 8. Fixed effects, random effects and pooled regression results for the relationship between R\&D tax incentives and sustainable corporate growth.

\begin{tabular}{|c|c|c|c|c|c|c|c|c|c|}
\hline \multirow{3}{*}{$\begin{array}{c}\text { Sample and } \\
\text { Dependent Variable }\end{array}$} & \multicolumn{3}{|c|}{ All Companies } & \multicolumn{3}{|c|}{ High-Tech Companies } & \multicolumn{3}{|c|}{ Low-Tech Companies } \\
\hline & \multicolumn{3}{|c|}{ NSG } & \multicolumn{3}{|c|}{ NSG } & \multicolumn{3}{|c|}{ NSG } \\
\hline & FE & RE & Pooled & FE & RE & Pooled & FE & RE & Pooled \\
\hline RDTIG & $1.7898^{* * *}$ & $1.6210^{* * *}$ & $1.5620^{* * *}$ & $2.0604^{* * *}$ & $1.7751^{* * *}$ & $1.7193^{* * *}$ & 0.7601 * & $1.0496^{* * *}$ & $1.0496^{* *}$ \\
\hline CAPEXG & $0.0239 * *$ & $0.0422 * * *$ & $0.0442^{* * *}$ & $0.0205 *$ & $0.0399 * * *$ & $0.0417^{* * *}$ & 0.0284 & $0.0572 * *$ & $0.0572 * *$ \\
\hline EMPG & $0.1971^{* * *}$ & $0.5157^{* * *}$ & $0.5427^{* * *}$ & $0.2184^{* * *}$ & $0.5497^{* * *}$ & $0.5710 * * *$ & $0.1754^{* *}$ & $0.4629 * * *$ & $0.4629^{* * *}$ \\
\hline YR2016 & $-0.9698 *$ & -0.5138 & -0.4784 & -0.7026 & $-0.1736^{* * *}$ & -0.1422 & -1.4751 & -1.5290 & -1.5290 \\
\hline Constant & $4.3111^{* * *}$ & $2.2316^{* * *}$ & $2.0752^{* * *}$ & $4.8395^{* * *}$ & $2.4544^{* * *}$ & $2.3165^{* * *}$ & $1.6453 *$ & 0.9941 & 0.9941 \\
\hline$R^{2}$ & 0.2882 & 0.3196 & 0.3197 & 0.2860 & 0.3154 & 0.3155 & 0.3007 & 0.3231 & 0.3239 \\
\hline Obs. & & 2744 & & & 2304 & & & 440 & \\
\hline
\end{tabular}

${ }^{*} p<0.05,{ }^{* *} p<0.01,{ }^{* * *} p<0.001$. 


\section{Discussion and Conclusions}

The paper provides some insight into the area of private R\&D expenditures and the most common tools of public support for R\&D in selected OECD countries. As the majority of countries around the world are aware that $R \& D$ investments are important for sustainable economic growth, their governments try to encourage companies to invest their additional private funds in R\&D activities by using different tools of public support for R\&D. The most common of these tools are direct funding through R\&D subsidies and indirect funding through R\&D tax incentives. In most OECD countries, both of these tools are available. This paper tries to add some value to the existing literature evaluating the impact of private $R \& D$ expenditures and $R \& D$ tax incentives on sustainable growth in selected OECD countries by utilising a unique database encompassing all relevant data regarding main resources of production, $\mathrm{R} \& \mathrm{D}$ tax incentives and corporate performance.

Using different econometric specifications of multiple regression analysis on a panel dataset of 1372 companies investing the largest amounts in R\&D activity in latest consecutive years, all of the proposed hypotheses are supported. The empirical results of this paper show a positive and significant impact of private $R \& D$ expenditures as well as $R \& D$ tax incentives (in interaction with private $R \& D$ expenditures) on sustainable corporate growth at the firm level in OECD countries. The comparison between different subgroups of companies reveals that private $R \& D$ expenditures represent one of the main driver of sustainable corporate growth especially in high-tech companies. Further, the empirical results reveal that $R \& D$ tax incentives (in interaction with private $R \& D$ expenditures) are key determinant of sustainable corporate growth in both subgroups of companies, whereby the impact is more prominent in high-tech companies.

The aforementioned results regarding private $R \& D$ expenditures and $R \& D$ tax incentives meaningfully complement to the existing literature, which is in general mostly focused on the relationship between private $R \& D$ expenditures and corporate performance. Nowadays, $R \& D$ investment becomes extremely important also from the aspect of policymakers, which usually play a major role in determining a business environment for companies as well as in designing different policies with the aim of facilitating their business operations. In terms of public support for R\&D investment, there is often a debate, who should be an appropriate beneficiary. Although this debate is more prevalent in the case of R\&D subsidies, the policymakers should also be aware the effect of $R \& D$ tax incentives on different subgroups of companies. The results of this paper can therefore help to clarify certain ambiguities regarding $R \& D$ tax incentives. At first glance, it seems that private $R \& D$ expenditures enhance sustainable corporate growth only in high-tech companies. However, when considering the simultaneous effect of $R \& D$ tax incentives the results reveal that they turn private R\&D expenditures to one of the main determinant of sustainable corporate growth also in low-tech companies. This can signalise to policymakers how an appropriate policy measure such as the introduction of $R \& D$ tax incentives can facilitate business operations of different subgroups of companies and consequently improve their corporate performance and enhance corporate sustainable growth. As it is evident from current trends, there is a shift towards indirect public support through $R \& D$ tax incentives suggesting that more and more governments use $R \& D$ tax incentives as a major tool for promoting private expenditures in OECD countries. Nevertheless, there are still some governments doubting whether the implementation of such measure is effective or not and the presented findings may encourage them to implement some encouraging R\&D policies.

The paper has also some limitations as due to the lack of firm level evidence regarding the use of $R \& D$ tax incentives, only a proxy for $R \& D$ tax incentives is used in the analysis. Therefore, it would be interesting to include in the analysis more specific firm-level data regarding R\&D tax incentives. Another potential limitation of this paper is that the empirical analysis is due to data constraints restricted to recent two consecutive years, namely 2015 and 2016. It would be interesting to extend the period of the analysis in order to examine the impact of private $R \& D$ expenditures and $R \& D$ tax incentives on sustainable corporate growth in time. Finally, the empirical analysis is based only on top corporate R\&D investors from selected OECD countries, which may affect generalization 
of the results. Nevertheless, the findings of this paper provide some new evidence to the existing literature addressing R\&D investment and related issues. The findings of the paper will be beneficial for academic and practice experts and may increase the awareness of companies on the importance of private $R \& D$ expenditures and $R \& D$ tax incentives and also can help governments in designing $R \& D$ tax incentives policy. Namely, R\&D investment is expected to be one of the key determinant driving corporate performance and sustainable corporate growth.

Supplementary Materials: The following are available online at http:/ /www.mdpi.com/2071-1050/10/7/2304/ s1.

Author Contributions: D.R. performed analysis and wrote the paper. A.A. supervised the work on the paper and revised it.

Funding: The authors acknowledge the financial support from the Slovenian Research Agency (research core funding No. P5-0093).

Conflicts of Interest: The authors declare no conflict of interest.

\section{References}

1. Aralica, Z;; Račić, D.; Redžepagić, D. Research and development activity as a growth factor of foreign owned SMEs in selected Central and Eastern European countries. Zb. Rad. Ekon. Fak. Rijec. 2008, 26, 279-300.

2. Aralica, Z.; Račić, D.; Redžepagić, D. R\&D activities as a growth factor of foreign-owned SMEs in Croatia. Croat. Econ. Surv. 2009, 11, 73-93.

3. Aristovnik, A. The relative efficiency of education and R\&D expenditures in the new EU member states. J. Bus. Econ. Manag. 2012, 13, 832-848. [CrossRef]

4. Aristovnik, A. Efficiency of the R\&D Sector in the EU-27 at the Regional Level: An Application of DEA. Lex Localis 2014, 12, 519-531. [CrossRef]

5. Streimikiene, D. The impact of research and development for business innovations in Lithuania. Amfiteatru Econ. 2014, 16, 965-979.

6. European Commission. Investing in Research: An Action Plan for Europe Communication from the Commission. 2003. Available online: http:/ / ec.europa.eu/invest-in-research/pdf/download_en/investing en.pdf (accessed on 5 May 2018).

7. European Commission. Europe 2020: A Strategy for Smart, Sustainable and Inclusive Growth. 2010. Available online: http:/ / ec.europa.eu/ eu2020/pdf/COMPLET\%20EN\%20BARROSO $\% 20 \% 20 \% 20007 \% 20$ \%20Europe $\% 202020 \% 20-\% 20$ EN\%20version.pdf (accessed on 5 May 2018).

8. OECD. OECD Science, Technology and Industry Scoreboard 2015: Innovation for Growth and Society. 2015. Available online: https://www.oecd-ilibrary.org/docserver/sti_scoreboard-2015-en.pdf? expires=1528475143\&id=id\&accname=guest\&checksum=1C7CCC46C57D5414B20581D79B998FF6 (accessed on 5 May 2018).

9. Deloitte. Central European Corporate R\&D Report 2016. 2016. Available online: https:/ /www2.deloitte. $\mathrm{com} / \mathrm{ce} / \mathrm{en} / \mathrm{pages} /$ about-deloitte/articles/rnd.html (accessed on 5 May 2018).

10. Ravšelj, D.; Aristovnik, A. R\&D Subsidies as Drivers of Corporate Performance in Slovenia: The Regional Perspective. Law Econ. Rev. 2017, 8, 79-95. [CrossRef]

11. Ravšelj, D.; Aristovnik, A. The Impact of the Crisis on Healthcare Risk Management in Slovenia: The Case of Regional Hospitals. Lex Localis 2016, 14, 493-511. [CrossRef]

12. Sullivan, P.H., Jr.; Sullivan, P.H., Sr. Valuing intangibles companies-An intellectual capital approach. J. Intellect. Cap. 2000, 1, 328-340. [CrossRef]

13. Czarnitzki, D.; Hottenrott, H. R\&D investment and financing constraints of small and medium-sized firms. Small Bus. Econ. 2011, 36, 65-83. [CrossRef]

14. Busom, I.; Corchuelo, B.; Martínez-Ros, E. Tax incentive or subsidies for business R\&D? Small Bus. Econ. 2014, 43, 571-596. [CrossRef]

15. OECD. OECD Science, Technology and Industry Scoreboard 2017: The Digital Transformation. 2017. Available online: https:/ / read.oecd-ilibrary.org/science-and-technology/oecd-science-technology-andindustry-scoreboard-2017_9789264268821-en\#page1 (accessed on 5 May 2018). 
16. Becker, B. Public R\&D policies and private R\&D investment: A survey of the empirical evidence. J. Econ. Surv. 2015, 29, 917-942. [CrossRef]

17. Dimos, C.; Pugh, G. The effectiveness of R\&D subsidies: A meta-regression analysis of the evaluation literature. Res. Policy 2016, 45, 797-815. [CrossRef]

18. International Monetary Fund. Fiscal Monitor: Acting Now, Acting Together. 2016. Available online: https:/ / www.imf.org/external/pubs/ft/fm/2016/01/pdf/fm1601.pdf (accessed on 5 May 2018).

19. OECD. OECD Business and Finance Outlook 2016. 2016. Available online: https://www.oecd.org/daf/ OECD-Business-Finance-Outlook-2016-Highlights.pdf (accessed on 5 May 2018).

20. Romer, P.M. Endogenous technological change. J. Polit. Econ. 1990, 98, 71-102. [CrossRef]

21. Grossman, G.M.; Helpman, E. Quality ladders in the theory of growth. Rev. Econ. Stud. 1991, 58, 43-61. [CrossRef]

22. Aghion, P.; Howitt, P. A model of growth through creative destruction. Econometrica 1992, 60, $323-351$. [CrossRef]

23. Silaghi, M.I.P.; Alexa, D.; Jude, C.; Litan, C. Do business and public sector research and development expenditures contribute to economic growth in Central and Eastern European Countries? A dynamic panel estimation. Econ. Model 2014, 36, 108-119. [CrossRef]

24. Armeanu, D.Ş.; Vintilă, G.; Gherghina, Ş.C. Empirical Study towards the Drivers of Sustainable Economic Growth in EU-28 Countries. Sustainability 2017, 10, 4. [CrossRef]

25. Toivanen, O.; Stoneman, P.; Bosworth, D. Innovation and the market value of UK firms, 1989-1995. Oxf. Bull. Econ. Stat. 2002, 64, 39-61. [CrossRef]

26. Le, S.A.; Walters, B.; Kroll, M. The moderating effects of external monitors on the relationship between R\&D spending and firm performance. J. Bus. Res. 2006, 59, 278-287. [CrossRef]

27. Foray, D.; Hall, B.H.; Mairesse, J. Pitfalls in estimating the returns to corporate R\&D using accounting data. In Proceedings of the First European Conference on Knowledge for Growth, Seville, Spain, 8-9 October 2009.

28. David, P.; O'Brien, J.P.; Yoshikawa, T. The implications of debt heterogeneity for R\&D investment and firm performance. Acad. Manag. J. 2008, 51, 165-181. [CrossRef]

29. Falk, M. Quantile estimates of the impact of R\&D intensity on firm performance. Small Bus. Econ. 2012, 39, 19-37. [CrossRef]

30. Rao, J.; Yu, Y.; Cao, Y. The effect that R\&D has on company performance: Comparative analysis based on listed companies of technique intensive industry in China and Japan. Int. J. Educ. Res. 2013, 1, 1-8.

31. Nica, A.M.; Stancu, I.; Stancu, D. Innovation. An Instrument for Development of Companies. Amfiteatru Econ. 2017, 19, 509-527.

32. Schimke, A.; Brenner, T. Temporal Structure of Firm Growth and the Impact of RED; Working Paper No. 32; ECONSTOR: Karlsruhe, Germany, 2011.

33. Arrow, K. Economic welfare and the allocation of resources for invention. In The Rate and Direction of Inventive Activity: Economic and Social Factors; Princeton University Press: Princeton, NJ, USA, 1962; pp. 609-626.

34. David, P.A.; Hall, B.H.; Toole, A.A. Is public R\&D a complement or substitute for private R\&D? A review of the econometric evidence. Res. Policy 2000, 29, 497-529. [CrossRef]

35. Hall, B.H. The financing of research and development. Oxf. Rev. Econ. Policy 2002, 18, 35-51. [CrossRef]

36. Svoboda, P. The Impact of Tax Incentives on Research and Development. Acta Univ. Agric. Fac. Silv. Mendel. Brun. 2007, 65, 737-743. [CrossRef]

37. Mamuneas, T.P.; Nadiri, M.I. Public R\&D policies and cost behavior of the US manufacturing industries. J. Public Econ. 1996, 63, 57-81. [CrossRef]

38. Hall, B.; Van Reenen, J. How effective are fiscal incentives for R\&D? A review of the evidence. Res. Policy 2000, 29, 449-469. [CrossRef]

39. Bloom, N.; Griffith, R.; Van Reenen, J. Do R\&D tax credits work? Evidence from a panel of countries 1979-1997. J. Public Econ. 2002, 85, 1-31. [CrossRef]

40. Baghana, R.; Mohnen, P.M. Effectiveness of R\&D tax incentives in small and large enterprises in Québec. Small Bus. Econ. 2000, 33, 91-107. [CrossRef]

41. Czarnitzki, D.; Hanel, P.; Rosa, J.M. Evaluating the impact of R\&D tax credits on innovation: A microeconometric study on Canadian firms. Res. Policy 2011, 40, 217-229. [CrossRef]

42. Kobayashi, Y. Effect of R\&D tax credits for SMEs in Japan: A microeconometric analysis focused on liquidity constraints. Small Bus. Econ. 2014, 42, 311-327. [CrossRef] 
43. Hanel, P. Impact of government support programs on innovation by Canadian manufacturing firms. In Proceedings of the International Conference on the Evaluation of Government Funded R\&D Activities, Vienna, Austria, 15-16 May 2003.

44. Soares, T.; Pereira, S.; Brandão, E. The Effects of RED Intensity and Tax Incentives on Firms' Growth-Empirical Evidence from World's Top RED Spending Firms between 2003 and 2012; Working Paper No. 540; University of Porto: Porto, Portugal, 2014.

45. Šeligová, M. The Effects of R\&D Intensity and Tax Incentives on Firms Growth of PIGS Countries. Eur. Financ. Account. J. 2016, 2, 53-68. [CrossRef]

46. European Commission. The 2016 EU Industrial R\&D Investment Scoreboard. 2016. Available online: http:/ / iri.jrc.ec.europa.eu/scoreboard16.html (accessed on 5 May 2018).

47. European Commission. The 2017 EU Industrial R\&D Investment Scoreboard. 2017. Available online: http:/ / iri.jrc.ec.europa.eu/scoreboard17.html (accessed on 5 May 2018).

48. OECD. R\&D Tax Incentive Indicators. 2017. Available online: http:/ / oe.cd/rdtax (accessed on 5 May 2018).

49. Gupta, P.D.; Guha, S.; Krishnaswami, S.S. Firm growth and its determinants. J. Innov. Entrep. 2013, 2, 1-15. [CrossRef]

50. Stewart, L.A.; Warda, J.; Atkinson, R.D. We're\# 27!: The United States Lags Far Behind in R\&D Tax Incentive Generosity. 2012. Available online: http:/ / www2.itif.org/2012-were-27-b-index-tax.pdf (accessed on 5 May 2018).

51. Torres-Reyna, O. Panel Data Analysis Fixed and Random Effects Using Stata (v. 4.2). 2007. Available online: https:/ / www.princeton.edu/ otorres/Panel101.pdf (accessed on 5 May 2018).

(C) 2018 by the authors. Licensee MDPI, Basel, Switzerland. This article is an open access article distributed under the terms and conditions of the Creative Commons Attribution (CC BY) license (http:/ / creativecommons.org/licenses/by/4.0/). 